\title{
Chapter 4 \\ The Atmosphere of Democracy: \\ Knowledge and Political Action
}

\author{
Nico Stehr
}

\section{Society and Nature}

It is well known that in recent years, the scientific community's consensus about man-made climate change has not only become more robust but that a number of recent studies point to far more dramatic and long-lasting consequences of global warming than previously assumed. Although commonly referred to simply as "global warming," the consequences to expect are increasing average global temperatures, rising sea levels, and more frequent occurrences of extreme weather. Given the accumulation of greenhouse gases in the atmosphere, their retention time of hundreds or more years and, despite many efforts to reduce emissions, enhance resilience, and implement new technologies, the relationship between society and the climate is bound to change in novel and unpredictable ways (see Stehr \& Machin, 2019).

Under the circumstances, how is it possible, many scientists now ask, that robust science-based evidence does not motivate and encourage major political action in society as a whole and change the conduct of civil society members worldwide? How is it possible that democracies in particular have done so little to effectively combat the risks of climate change and simply failed to pay attention to the dangers

In my discussion of the relation between knowledge, expertise, and democracy, I am drawing on a couple of earlier reflections, such as Stehr (2016a, 2016b). I am grateful to Michael Handke for his comprehensive and constructive review of my manuscript. I thank Scott McNall for his helpful comments.

N. Stehr $(\bowtie)$

Karl Mannheim Chair for Cultural Studies, Zeppelin University, Friedrichshafen, Germany

e-mail: nico.stehr@t-online.de

J. Glückler et al. (eds.), Knowledge for Governance, Knowledge and Space 15,

https://doi.org/10.1007/978-3-030-47150-7_4 
of global warming? ${ }^{1}$ After all, the nature of the future present is very much predicated on decisions taken now.

Being disenchanted with the workings of democracy and blaming democracy for a host of social, economic, and political ills is not a new complaint: "Lamenting the failings of democracy is a permanent feature of democratic life, one that persists through governmental crises and successes alike" (Runciman, 2013). However, the referent of the expression "climate change" is a novel reason for a fundamental concern about the fate and future of democracy.

\section{Blaming Democracy}

Climate scientists, social scientists, and the media as well as environmental activist groups (NGOs) concerned with climate change refer to a "future present" of exceptional circumstances ${ }^{2}$ and protest that "evolution did not design us to deal with such problems" (Jamieson, 2014, p. 61; di Paola \& Jamieson, 2018). ${ }^{3}$ Members of the same groups assert impatiently that no one is listening to the diagnosis of historically unprecedented risks and dangers. ${ }^{4}$

In important respects, therefore, the discourse of climate science having established the fact of anthropogenic climate change has by necessity become forward looking. The focus has shifted to how will it be possible to govern societies in the not too distant future under the massive impact of global warming. How will it be

\footnotetext{
${ }^{1}$ I am using the concepts of "risk" and "dangers" not as overlapping terms, but in the sense in which Niklas Luhmann (2005, p. 23) introduced them as contrasting concepts. The risks of climate change can be attributed human-made decisions, while humanity is exposed to the dangers of climate change. An example of risk-taking decisions related to climate change can be studied in today's State of California: People are moving into high fire-risk zones, that is, the population of California grew by 3 million between 2000 and 2010, and, “in 2017 over a quarter of the state's population lived near moderate or high-risk fire corridors. With this increase in population comes a higher possibility of a human-made wildfire. And as people move into these high-risk areas, more buildings are in harm's way: structures generally burn longer than vegetation, allowing fire more time to spread" (cf. Adolphe, 2018).

${ }^{2}$ The useful concept of a "future present" is Niklas Luhmann's (1976, p. 140) terminology: "If we characterize processes or activities as beginning or ending, we use a terminology which belongs to the present. If we use these expressions to refer to distant dates-for example: The Roman Empire began to fall-we refer to a past present or to a future present."

${ }^{3}$ An incessant amplification in the discourse of imminent threats (many may recall the 1986 SPIEGEL title with Cologne cathedral underwater) can paradoxically turn out to be supportive of the opposite virtue, namely, as a defense of the present and encouraging skepticism toward scenarios of impending dangers. This represents a psychological mechanism not unlike the everyday attitude toward weather extremes widely interpreted as an affirmation of the normal course of the climate (cf. Stehr, 1997; Stehr \& Machin, 2016b, 2019).

${ }^{4}$ As Bill McKibben (2018), for example, notes: “Over and over we've gotten scientific wake-up calls, and over and over we've hit the snooze button. If we keep doing that, climate change will no longer be a problem, because calling something a problem implies there's still a solution."
} 
possible to govern a future present that is anticipated to be altogether different from the societal context in which democratic systems originated and flourished in the past? In the cases which I will identify, strong opinions promoting the need to suppress political liberties in the wake of profound future environmental changes are no longer unusual, yet have not received systematic attention in social science.

In this essay, therefore, I will bring this disenchantment with democracy, especially in its currently dominant liberal version, under the spotlight. My essay is about the struggle to align politics and policy with science. I will critically probe the argument that policy makers are going to have to act, even without a broad public mandate and legitimacy. Time is very short before a future of disastrous damage becomes locked in. But rather than lamenting the inconvenience of democratic governance, it is important to reflect upon ways of enhancing democracy, not despite but especially in light of the massive challenges of a changing climate. Coping with major environmental challenges is best accomplished, as history shows and as I will argue, within the bounds of democratic rather authoritarian political systems. In this essay, I reframe our changing climate as an issue of political governance and not as merely an environmental or as an economic issue.

I will advance my argument in a number of steps. First, I will address the growing assertion that social science contemporary democracies face exceptional circumstances. Second, I will reflect on the classical and present-day social science discourse on the erosion of the foundations of democracy. Third, I will describe the growing sentiment of an inconvenient democracy among climate scientists, other scholars, NGOs, and the media. Climate scientists propose overcoming modern democracies' inability to cope with the disastrous consequences of climate change by abolishing democracy. The alternative, of course, is to strengthen democracy. Fourth, I will consider the proposed shift in role for climate scientists as policy makers. In the final section, I will examine the serious deficiencies in the assertion of contemporary society as an inconvenient democracy.

\section{The Rise of Exceptional Circumstances}

As never before, the continuity from past to future is broken in our time. Niklas Luhmann (1998, p. 67).

In the past, actors typically used war-like conditions and major disasters to justify the abolition of democratic liberties, if only temporarily. The present appeal to exceptional circumstances from the critics of dominant government climate policies around the world echoes this sentiment, demanding the elevation of a single sociopolitical purpose to ultimate political supremacy. ${ }^{5}$

\footnotetext{
${ }^{5}$ For a discussion of exceptionalism in political theory, critical security, and citizenship studies, see Best (2018).
} 
With climate change, the world is confronted with a historically novel situation and future present. Climate change within historical times is locked in. Most of the scientific discourse has been devoted to establishing that anthropogenic climate change exists. Researchers have settled the issue of whether climate change is anthropogenic, and it has become clear that unless increasingly vigorous political, economic, and societal measures are implemented, the planet will continue to experience warming "greater than it has been for more than half a million years" (Nordhaus, 2013, p. 325). What scientists have not settled is a range of important questions such as the speed of global warming, or the nature of the consequences of climate change on various significant attributes of human existence and in different regions of the world.

Governing the consequences of climate change must include a time scale and anticipated societal transformations that are clearly beyond human imagination and current political institutions. Except for reference to singular historical events, such as war, revolution, economic collapse, or the struggle for national liberation, there are no large-scale human experiences within historical times to which the climate science community can appeal as it begins to reflect on a future present in which massive impacts of climate change have set in. This relates to all levels of society and its relations abroad, such as how the world makes and uses energy, the virtue of the nation state, migration patterns, the global economy, and civil societies. In such contexts, crisis conditions promote the creation of emergency powers, the delegitimation of the previous political order, the abolition of liberty and justice, and the installment of revolutionary governance. The past is by no means a foolproof guide to the future-it is, however, often the only guide we have.

Appeal is therefore made to extraordinary circumstances or a war-like footing (Lovelock, 2009; McKibben, 2016) that necessitates the suspension of freedoms and climate scientists' political ascent. As the French political scientist Pierre Rosanvallon (2013, p. 184) stresses: "The central nation state is seen as the only source of security in the face of radical risk. It is the hope that an appeal to extraordinary circumstances, that is, to a threat to the very existence of civilization if not humankind alone might be able to give capacity and ... energy back to a failing or hampered [political] will." Frank Fischer (2017, p. 54) complements this in criticizing that "current political-economic efforts on part of contemporary democratic systems to deal with problems such as global warming ... [are] little more than limited symbolic gestures, especially given the pressing constraints of time." The problem of global warming and its consequences does not merely pertain to contemporary democratic governance and a missing commitment of citizens to change their ambitions and behavior. Above all, a future perspective is needed (Lovelock, 2009). The future perspective imposes its own norms on the present (cf. Jonas, 1984, p. 143). ${ }^{6}$

\footnotetext{
${ }^{6}$ Hans Jonas (1984, p. 143) interrogates the Baconian idea (executed, e.g., within Marxism) of dominating nature by increasing the humanity's power over it in his search for an ethic of the technological age. Jonas designates the Baconian ideal as the source of an ethic aimed predominantly at the future and therefore imposes its norms on the present.
} 
But how does one govern well under exceptional circumstances? This question encounters two countervailing forces: that of an inconvenient mind ${ }^{7}$ and of inconvenient social institutions. The former relates to a public that is assumed to be "presentcentric" (Skidelsky \& Skidelsky, 2012, p. 130), in other words, comfortable with the status quo, and that justifies imposing one's own (superior) ideas on those of future generations citizens (because should one really need to care whether the future public cares?). The latter relates to a strong state in the form of a command society. In other terms, good governance of society based on citizen participation must be subordinated by almost any means to the defeat of the exceptional circumstances.

It is the single purpose of defeating those exceptional circumstances that legitimizes the temporal suspension of liberties (Hayek, 1944, p. 189). However, is any massive absorption of powers in the hand of the state and its representative's reversible, in the long run? And are the potential consequences of climate change the equivalent of (abrupt) war-like conditions? How can one pinpoint the onset of exceptional circumstances?

Democratic governments' deficiencies are many and far exceed the issue of climate change and its societal consequences; but is it therefore justified to reach a conclusion as disparaging as the diagnosis of an inconvenient democracy? After all, authoritarian and totalitarian governments do not have a record of environmental accomplishments; nations that have followed the path of "authoritarian modernizat ion/environmentalism" such as China or Russia cannot claim to have a better record. ${ }^{8}$ Nonetheless, the disenchantment with democracies continues to be advanced, and perhaps is becoming even more vocal as entrenched climate policies fail to live up to their promise.

\section{Inconvenient Democracy}

Those who assert exceptional circumstances and the concomitant promotion of the need to overcome an inconvenient democracy derive their intellectual sustenance from a range of new and classical considerations, which lead to different forms of blaming with different addressees.

\footnotetext{
${ }^{7}$ The reference to the inconvenient mind is of course a play on words rooted in the better-known metaphor "an inconvenient truth." A fairly straightforward example of an inconvenient mind in the case of climate change is to suggest that the science of climate change is much too complicated for the average citizen to comprehend. A less "neutral" version of the inconvenient mind would be to suggest that the public is intellectually incapable of grasping the idea of global warming and its consequences.

${ }^{8}$ As Bruce Gilley (2012, p. 287) explains, "authoritarian environmentalism" is used to refer to "an emerging theory of public policymaking in the face of severe environmental challenges. It has been discussed both as a prescriptive model of how countries should effectively respond to such challenges, and as a descriptive model of how they are likely to respond."
} 


\section{The Erosion of Democracy: The Classical Perspective}

In the classical social science literature, many observers believe that the threat to democracy that issues from an uneven access and distribution of knowledge in societies, for example, on social inequality formation in society (see Stehr \& Machin, 2016a), has radically displaced earlier, optimistic enlightenment views regarding the resilience and even the possibility of a democracy based on a general circulation of knowledge in society. ${ }^{9}$ Numerous authors, from Max Weber to Robert Michels, have explicated these and other threats to representative democracy.

Given the unstoppable advance of bureaucracy in modern societies, Max Weber (1918/1994), for example, feared a kind of pacifism of social impotence of the citizenry, for in the face of a

growing indispensability and hence increasing power of state officialdom ... how can there be any guarantee that forces exist which can impose limits on the enormous, crushing power of this constantly growing stratum of society and control it effectively? How is democracy even in this restricted sense to be at all possible? (Weber, 1918/1994, p. 159)

Robert Michels (1915), in his classical study of the undemocratic tendencies in the social democratic party, a political organization that actually aspires to and fights for democratic goals, refers to an almost "natural" state of incompetence and immaturity of the mass of people in modern democracies. And because those of rank and file are incapable "... of looking after their own interests, it is necessary that they should have experts to attend to their affairs" (Michels, 1915, p. 93). Seldom is the rank and file willing to throw off the authority of the expert leaders and dismiss them from control. ${ }^{10}$ Numerous of the classical concerns about the viability of democratic governance find an echo in contemporary reflections about the fragility of democracy.

\footnotetext{
${ }^{9}$ There is good reason to be skeptical of the idea that either the notion or the realities of the knowledge gap or the information overload, however defined, are genuinely new. One has only to refer to the convergence of societal diagnoses proposed, at the dawn of the last century, by thinkers such as Georg Simmel, Sigmund Freud, and Walter Benjamin, of a cultural age displaying severe overstimulation, discontinuities, and overload.

${ }^{10}$ Whether the disillusioned conclusion Robert Michels (1915, p. 95) draws in light of the tendencies he observes, namely that "social democracy is not democracy, but a party fighting to attain democracy" is inevitable, that is, universally applicable as a kind of iron law, is surely contestable, although many observers are prepared to concede that Michels has discovered one of the few lawlike relations in social science. For more recent studies by economists, sociologists, and political scientists who take Michels's challenge about the inevitability of oligarchic tendencies in organizations on board, see Williamson (1975, 1985, 1994), Granovetter (1985), Foucault (2005), Stehr and Adolf (2018, pp. 321-324).
} 


\section{The Erosion of Democracy: The Modern Perspective}

A deep-rooted pessimism about the psychological make-up of human beings, the temporality of human thought, the failure to mobilize individuals for the cause of effective climate policies, the inability of government given constitutional constraints to attend to long-term goals, the fragility of the political order, the influence of vested interests on the political agendas of the day, and in the case of anthropogenic climate change, the addiction to fossil fuel, as well as, last but not least, the ineffectiveness of the climate science community itself insure that their message does not fall on deaf ears. ${ }^{11}$

\section{Blaming the People}

Daniel Kahneman sums up the growing skepticism regarding citizen motivation when he states:

The bottom line is that I'm extremely skeptical that we can cope with climate change. To mobilize people, this has to become an emotional issue. It has to have the immediacy and salience. A distant, abstract, and disputed threat just doesn't have the necessary characteristics for seriously mobilizing public opinion. (Cited in Marshall, 2014, p. 57, emphasis added)

The mass of citizens, it seems, simply cannot be won over to endorse and follow the course of scientifically based policy options. The large majority of citizens is basically inclined to act irrationally (cf. Schumpeter, 1942, pp. 262-263). The climate scientist Hans-Joachim Schellnhuber (Elger \& Schwägerl, 2011, p. 29) ${ }^{12}$ gloomily relates why climate change communication does not reach civil society: "[M]y own experience and everyday knowledge illustrate that comfort and ignorance are the biggest flaws of human character. This is a potentially deadly mix." However, to view democracy and politics in terms of the competence of the individual citizens is to argue in favor of a micro-sociology without a macro-sociology. The reference to the public perceptions of science and expert knowledge goes beyond the implicit or explicit assumption that the public has basically deficient information and knowledge, is perhaps even reactionary, and tends to respond to complexity with trepidation (cf. Gauchat \& Andrews, 2018).

The apparently widely shared ability to avoid knowing what the future could bring can of course also be interpreted as a psychological "incentive" to live with

\footnotetext{
${ }^{11}$ Efforts in climate change communication are predicated on the conviction that if the public only knew the facts about climate change and began to understand just how serious the problem is, they would raise their voices and demand that our governments and corporations do something (Revkin, 2014).

${ }^{12}$ The climate scientist Hans Joachim Schellnhuber, in an interview with DER SPIEGEL (Issue 12, March 21st, 2011, p. 29) in response to the question of why science's messages do not reach society.
} 
the knowledge about the limited knowledge on the outcome of events that are located in the future (cf. Gigerenzer \& Garcia-Rettamero, 2017). Meanwhile, political scientists, who have in many ways been concerned about the voters' lack of information, have begun to stress that the democratic-political system works in spite of citizens' ignorance (Kuklinski, 1990). Or, as Petersen and Aarøe (2013, p. 289) have more recently documented, despite the widespread lack of extensive political knowledge, "citizens readily form opinions on what constitutes the best and most efficient policies."

Seymour Martin Lipset and his colleagues (1962) advance an appraisal more in support of the political virtue of knowledgeable citizens: lack of information, passivity, and lack of interest of rank-and-file members in the affairs of an organization is in the interests of the powerful and supports their capacity to perpetuate power advantages. It seems that it is not so much the volume of knowledge or information that citizens command that impacts the relation between democracy and knowledge, but rather the importance of democracy-enhancing individual and collectively shared value-orientations; or, as Robert Dahl (1977, p. 1) argues: It is "the ways in which we think about ourselves as a people" that support the existence and the stability of democracy. Of course, value-orientations and educational achievement are connected: "Education presumably broadens men's outlook, enables them to understand the need for norms of tolerance, restrains them from adhering to extremist and monistic doctrines, and increases their capacity to make rational electoral choices" (Lipset, 1959, p. 79).

\section{Blaming the Political Class}

In the eyes of many from the climate science community, not only citizens but also politicians are not ready to pursue policies that effectively address climate change. Climate activist, climate scientists, some politicians, and many other observers agree that the recent climate summits in Copenhagen, Cancun, Durban, and Warsaw were failures. The summits did not result in a new global agreement to cope with the emissions of greenhouse gases. The subsequent 2015 Paris Agreement, widely regarded as an historical achievement, seemingly marks a general scientific and public consensus that anthropogenic climate change is a very serious threat to human civilization and its environments. The treaty, however, is non-binding. There are no formal sanctions if a country should fail to live up to its commitments regarding the efforts in terms of mitigation, adaptation, or finance, and there is no guarantee how far reaching the Paris Agreement will be. This problem came to the fore on June 1st, 2017, when the United States, led by President Donald Trump, announced their formal withdrawal from the treaty, rejecting the scientific consensus that greenhouse gas emissions are warming the planet.

Although under the terms of the Paris Agreement the U.S. cannot formally begin the process of withdrawal until November 2019, the current administration is already embarked upon a strong anti-environmentalist agenda. In his 
announcement, Trump was fulfilling his campaign pledge to "end the war on coal" and his purported aim to reclaim sovereignty for the American people and put "America first." But as has been much remarked upon, shortly after his announcement in which Trump emphasized that he was elected to represent "the people of Pittsburgh and not Paris," the mayor of the state of Pittsburgh, Bill Peduto, voiced his criticism of the withdrawal and proclaimed the state's commitment to the treaty. Indeed, a number of American states and cities will continue to follow its announced climate policies, offering "a profound counter to Trump's anti-environmental crusade" (Bomberg, 2017, p. 5). What this scenario illustrates is the high degree of politicization of the issues of climate and climate change in the contemporary world.

The nature of the relation between temporality and democracy indeed justifies doubts about the effectives of democratic governance in the face of longer-term future risks and dangers of climate change. Issues of temporality refer to at least a couple of significant matters driven by distinctive but related systemic conditions of democratic governance. On the one hand, democratic governance is captivated by the immediacy of frequently changing events that often come and go rapidly, as much as it is affected, on the other hand, by constitutional rules of representation that prescribe relatively short frames of temporality. The public perception of the urgency of political issues is dynamic and relative. The attention that actors give to climate change very much depends on their perception of the importance of other political issues at any given time, especially on the perception of pressing economic issues.

Are democracy and societal institutions constrained by short-term constitutional frames and governed by principles of liberty, such as the market, capable of dealing with harms and risks to society that are located in the future? How can democracies sustain interest in a future present that is a couple of decades away and thereby escaping the typical media issue attention cycle (Downs, 1972; McDonald, 2009) of events?

There is a parallel discourse in social science to which I now turn, in which scientists express strong doubts about the "sustainability" of modern democracies. They highlight symptoms of a crisis that is not only triggered by major environmental problems but also by various structural and secular challenges faced by presentday democratic governance.

\section{Are Democracies Dying?}

The climate science community's discussions about democratic governance's inadequacies converges with assessments of the present state and future of democracy in the social sciences. It was only a few years ago that political scientists proclaimed the end to history (Fukuyama, 2018) and with it the ultimate victory of democracy. Today, political scientists—Francis Fukuyama (2018) included—are much more likely contemplating the dissolution of democracy. Even titles like "The Future of Freedom" (Zakaria, 2003), "The Retreat of Western Liberalism” (Luce, 2017), 
"How Democracy Ends" (Runciman, 2018), "How Democracies Die" (Levitsky \& Ziblatt, 2018), "The People vs. Democracy" (Mounk, 2018), and "Can Democracy Survive Global Capitalism? (Kuttner, 2018) give an indication of it. The dispute about climate change and climate policies plays a central role in the contemporary shift of the debate about the well-being of democracy. In response to multiple societal changes underway, the arguers concludes, democracy loses its legitimacy in the eyes of its citizens.

The conclusion of social science observers must therefore be that contemporary democracy - in many ways whether by design or at the outcome of structural economic, political and moral changes - is on its way to autocratic forms of governance. For instance, the erosion of democracy manifests itself in processes of de-politicization, the substitution of politics by techniques of management or the restriction of the public sphere, or (cf. Rosanvallon, 2006, p. 228; also Swyngedouw, 2011) "in a hollowing out of citizenship, the marketization of the public sector, the soul-destroying targets and audits that go with it, the denigration of professionalism and the professional ethic, and the erosion of public trust" (Marquand, 2004, p. 172). Democratic governance is increasingly muted by the rapid abolition of democratic principles of political equality, and even replaced by autocratic forms of governance that echo Robert Michels's (1915) century-old iron law of oligarchy.

What distinguishes the discussion about the poor health of democracy among social scientists and climate scientists is the remedy that both sides advocate. On the one hand, social scientists discuss efforts that could restore democracy, such as rebuilding "a society of similar individuals" (Rosanvallon, 2013) through the active participation of a large number of citizens that shaping the agenda of public life. On the other hand, climate scientists and other observers of global climate change disparage democratic governance's very capacity to cope effectively with the largescale environmental problems and therefore call for a more authoritarian state and/ or a state where decision making by technical experts is given weight. But then democracy is allegedly dismantling itself.

Colin Crouch (2004, p. 4), for example, describes democracy's transition to postdemocracy in the following terms: "Under the conditions of a post-democracy that increasingly cedes power to business lobbies, there is little hope for an agenda of strong egalitarian policies for the redistribution of power and wealth, or for the restraint of powerful interests."

Post-democracy is also accompanied by the swift erosion and disavowal of democratic rights and values, as Richard Rorty (2004, p. 10) argues:

At the end of this process of erosion, democracy would have been replaced by something quite different. This would probably be neither military dictatorship nor Orwellian totalitarianism, but rather a relatively benevolent despotism, imposed by what would gradually become a hereditary nomenklatura.

In some of the images of post-democracy as a state of the state, a return to aristocratic society has already been achieved. Self-appointed elites claim to carry out 
the wishes of the masses. ${ }^{13}$ In short, as Pierre Rosanvallon (2006, p. 228) emphasizes, politics has been replaced, "leaving room for one sole actor on the scene: international society, uniting under the same banner the champions of the market and the prophets of the law." This marks a political development that representatives of the climate science community very much welcome.

The radical conclusion some observers draw, especially those who favor and promote the role of experts and expertise as a form of enlightened leadership, is that democracy itself is inappropriate, that the slow procedures for the implementation and management of specific, policy-relevant scientific knowledge leads to massive, unknown risks and dangers. Civilization-as-we-know-it may come to an end. Assuming it is not already too late, appropriate environmental governance must look very different. To create a globally sustainable way of life, the world immediately needs, in the words of German climate scientist Hans Joachim Schellnhuber (cf. WBGU, 2012), a "great transformation." Part, if not the core of the required great transformation appeared to be a new political regime and forms of governance. For example, as expressed by the Australian scholars David Shearman and Joseph Wayne Smith (2007, p. 12) in their book The Climate Change Challenge and the Failure of Democracy: "We need an authoritarian form of government in order to implement the scientific consensus on greenhouse gas emissions." Mark Beeson (2010, p. 289) argues in the same vein when he brings into play the notion of good authoritarianism:

$[G]$ iven the unprecedented and unforgiving nature of the challenges we collectively face ... forms of 'good' authoritarianism, in which environmentally unsustainable forms of behavior are simply forbidden, may become not only justifiable, but essential for the survival of humanity in anything approaching a civilised form.

Another proposal is for a distinctively political role of climate scientists. In most countries, climate scientists are successful in equipping governments with the authority of the correct point of view about climate change. However, climate scientists fail to ensure that governments act on the authority of science. What is the alternative? One alternative is an exchange of leadership and the rule of the knowledgeable class. The idea to exchange political leadership is not only to put science and scientists at the center of governance, but also to depoliticize the issue of climate change (cf. Aitken, 2012; Swyngedouw, 2010).

\footnotetext{
${ }^{13}$ Hans Jonas's (1984, p. 147) sober response to such a claim is quite appropriate and worth citing in this context: "[I]f ... only an elite can assume, ethically and intellectually, the kind of responsibility for the future which we have postulated-how is such an elite generated and recruited, and how is it invested with the power for its exercise?"
} 


\section{Enlightened Leadership?}

Within the broad field of climatology and climate policy, one is able to discern growing frustration with the virtues of democracy and a mounting appeal to exceptional circumstances and the promotion of the role of scientists and experts in policy making. The impatience with democracy and the shifting understanding of the role of scientists can be observed with a change in the function of the International Panel of Climate Change (IPCC). IPCC no longer considers itself a scientific organization with the mandate to offer alternative policy options for political discussion and decision, but a body of experts demanding that the options for political action it identifies be rapidly realized.

Robert Stavins, the director of Harvard's Environmental Economics Program and a co-author of the IPCC Working Group 3 report, notes a

bottom up demand which normally we always want to have and rely on in a representative democracy, is in my view unlikely to work in the case of climate change policy as it has for other environmental problems ... It's going to take enlightened leadership, leaders that take the lead. ${ }^{14}$

The social scientist Evelyn Fox Keller (2017, p. 107) makes the strong case for an immediately effective, practical political role of climate science, given the seriousness of the problem of global warming:

There is no escaping our dependence on experts; we have no choice but to call on those (in this case, our climate scientists) who have the necessary expertise ... Furthermore, for the particular task of getting beyond our current impasse, I also suggest that climate scientists may be the only ones in a position to take the lead ... [and] given the tacit contract between scientists and the state which supports them on the other, I ... also argue that climate scientists are not only in a position to take the lead, but also that they are obliged to do so.

\section{Science, Knowledge, and Democracy}

The strong desire to reach specific policy outcomes spelled out by the climate science community lead many to believe that scientific knowledge is somehow immediately performative or is an immediately persuasive form of knowing. Endorsers of such a conception of knowledge privilege knowledge as a policy instrument by ignoring the limits of the power of knowledge (Prewitt, 2010; Sarewitz, 2010; Stehr, 1991). On this doubtful basis alone, it is unsurprising that climate scientists at least sympathize with the suspension of democratic process.

However, the inconvenient democracy position contains a number of obvious weaknesses that I will enumerate now in some detail. I have organized my observations into five counterarguments.

\footnotetext{
${ }^{14}$ As quoted in Andrew Revkin, "A risk analyst explains why climate change risk misperception doesn't necessarily matter," New York Times, April 16th, 2014.
} 
First, and importantly, one encounters a flawed understanding of scientific knowledge and its potential role in political contexts. Scientific knowledge is neither immediately performative (knowledge equals control and represents practical reason) nor immediately persuasive (that is, knowledge convinces unencumbered). Knowledge alone does not generate a profit or score goals (cf. van Dijk, 2014). One of the fundamental flaws in the portrait of an inconvenient democracy is the failure to recognize the social character of knowledge in general and the contested and often ambivalent nature of political knowledge in particular. Recognizing the proper function of knowledge assures a premature political closure, in other words, the depoliticization of the issue of climate change and climate policies.

It is more appropriate to characterize knowledge not as "something that is so," but as a generalized capacity to act on the world, as a model for reality, or as the ability to set something in motion (Grundmann \& Stehr, 2012; Stehr, 1994; Stehr \& Adolf, 2018). The German term that best describes knowledge as a generalized capacity to act would be Handlungsvermögen. The verb vermögen signals "to be able to do," whereas the noun Vermögen, in this context, is best translated as "capacity" (rather than "fortune" or "wealth"). ${ }^{15}$ The capacity to act-the ability to put something into motion-extends to the capacity to generate "symbolic action." For example, symbolic action may involve the ability to formulate a hypothesis, carry out a ritual, find a new metaphor for an established term, ${ }^{16}$ assess "facts," organize the literature on a topic, or defend a thesis against "new facts." The capacity to act, in other words, refers not merely to the possibility of accomplishing something in terms of a material and physical performance such as, for example, making fire or driving a car. Capacities to act also refer to intellectual abilities as well as the production of meaning, such as may be found in the detailed description of the bundle of skills that I call knowledgeability (cf. Stehr, 2016a). This is most likely also the reason why Norbert Elias (1984, p. 252) defines knowledge as "the social meaning of human-made symbols, such as words or figures, in its capacity as means of orientation" (emphasis added).

Knowledge, as a generalized capacity for action, acquires an "active" role (that is, is put to work) in the course of social action only under certain circumstances, namely where social action does not follow purely stereotypical (effortless) patterns (Max Weber), or is strictly regulated in some other fashion. Under conditions of ritualized social conduct, a break in the continuity between past and future will not occur. Past and future are securely looked in through taken-for-granted sequences of events.

Niklas Luhmann's observations about the conditions for the possibility of making decisions in the first instance perhaps allows for an even broader understanding of the use of knowledge but also confirms my description of the likely usefulness of

\footnotetext{
${ }^{15}$ Georg Simmel (1890, p. 276), in his discussion of money as a generalized code, uses the concept Vermögen to describe the fact that money is more than merely a medium of exchange; his definition of money thus transcends a merely functional understanding of its social capacities.

${ }^{16}$ I refer in this context, for example, to Donald Schon's (1963) reflections in Displacement of Concepts (cf. also Haldane, 2013).
} 
knowledge only under conditions of degrees of openness of the circumstances of action. Decision making, Luhmann (1998, p. 67) writes, "is possible only if and insofar as what will happen is uncertain."

The circumstances of action that I have in mind may also be described as actors' capacity to alter or stabilize a specific reality. However, the capacity "to get things done," to alter and affect reality, as well as the ability to intervene in a context that otherwise would change, is not symmetrical with the capacity to act (knowledge). Knowledge and control should not be symmetrical: "Foresight and control is highly fragile in reality, it can be shown that a persistent progress of knowledge neither leads necessarily to an improvement of foresight nor to an improvement of control" (Tenbruck, 1977, p. 223). One's ability to do something is dependent on one's control over the conditions of action. The lack of control over the political conditions of action is an apt description of the societal role that fits the position of climate scientists today and will continues to be the case as long as they have not appropriated political power.

Second, one of climate science critics' leading assumptions of democracy is a misunderstanding of the climate problem and a misleading framing of the policy process. ${ }^{17}$ The result of this misunderstanding of the climate problem and of the climate policy process is a fundamental framing error, its perpetrators representing climate change as a conventional environmental "problem" that is capable of being "solved." It is neither of these.

Rather than being a discrete problem to be solved, climate change is better understood as a persistent condition that must be coped with and can only be partially managed more or less well. The climate issue is one part of a larger complex of such conditions encompassing population, technology, wealth disparities, public values, resource use, and so on. Hence, it is not straightforwardly an "environmental" problem either. It is axiomatically as much an energy problem, an economic development problem, or a land-use problem and may be better approached through these multiple avenues than as a problem of managing the behavior of the Earth's climate by changing the way that humans use energy.

This makes climate change a "wicked" problem. ${ }^{18} \mathrm{~A}$ wicked problem is the impossibility of giving the policy issue a definitive formulation: the information needed to understand the problem is dependent upon one's idea for solving it. Furthermore, wicked problems lack a stopping rule: One cannot know whether one has a sufficient understanding to stop searching for more understanding. There is no end to causal chains in interacting open systems of which the climate is the world's prime example. Climate change policies are best embedded in comprehensive policy perspectives whose holders attack climate change indirectly, accepting, for

\footnotetext{
${ }^{17}$ In my critique of the dominant framing of the climate problem, I draw on our Hartwell Paper (Prins et al., 2010).

${ }^{18}$ Wicked problems are embedded in multiple social systems. Originally described by C. West Churchman (1967) and later explicated more comprehensively by Horst Rittel and Melvin Webber (1973) in the context of urban planning, wicked problems are issues that are often formulated as if they were susceptible to a simple, unilinear solution when in fact they are not.
} 
example, that decarbonization will only be achieved successfully as a benefit contingent upon other goals that are politically attractive and pragmatic.

Third, in a related manner, proponents of the dominant political approach concentrate almost exclusively on a single effect that governance ought to achieve, namely a reduction of greenhouse gas emissions and perhaps necessary measures of adaptation to climate change. In doing so, they exclude other, more complex forms and conditions of action. By focusing on the goals of political action rather than its conditions, they reduce the contentious issue of climate change to scientific or technical issues. Sociopolitical issues are neglected. The politicization of climate science leads to a depolitization of climate changes. Matters relevant to the public are being permanently removed from politics (see also Jasanoff, 2012).

Equally deficient in this context is the focus on a single approach to attack climate change, namely a reduction of greenhouse gases, especially CO2. Those exclusively framing climate policy as directed toward a reduction of emissions ignore what Roger Pielke Jr. (2010) calls the "iron law" of climate policy. The iron law merely states that although people are often willing to pay a certain price for environmental policy goals, their willingness has its limits. That exact limit, of course, varies from place to place and household to household. The massive resistance of the "Yellow Vest" protests in France against the government's plans to implement regular fuel tax increases to fight global warming in the early winter of 2018 is a perfect example of Pielke's law. The protests of the Yellow Vest movement forced the government to cancel the tax increase. Public support for climate policies declines as a function of the impact of such policies on the household costs. A convergence of ecological and economic policies is not impossible. However, such a convergence likely tilts toward the economic part of the equation when emission reduction policies collide with economic growth or labor market policies.

Fourth, the generally pessimistic assessment of the ability of democratic governance to respond to, cope with, and control exceptional circumstances is linked, if only implicitly, to the then peculiar optimistic assessment of the potential of largescale planning in the sense of social engineering. Planning on any scale is hardly straightforward. Not only the capacity of governments but also the general possibility to plan for the future present of societies is rather limited, perhaps absent (see Tenbruck, 1977, p. 138). Economic and social planning conceptions widely discussed in the affirmative decades ago have fallen into disrepute (see Giddens, 2009, pp. 94-100). Certain schemes to improve the human condition have failed, James Scott (1998) demonstrates case-by-case in his book Seeing like a State. The once active academic program of, and enthusiastic support for, futurology about desirable futures has vanished (Seefried, 2015). Modern de-centered, functionally differentiated societies preclude de-differentiated, society-wide social planning in principle (Luhmann, 1976, 1998).

Fifth, in the reasoning of the impatient critics of democracy, one notes an inappropriate fusion of nature and the nature of society. The uncertainties (related to climate) that the sciences of the natural processes claim to have eliminated and the authoritative consensus that the sciences have thereby acquired are simply transferred to the domain of societal processes. Consensus on the evidence, it is argued, 
should motivate a consensus on political action. What becomes desirable is a rational design of social order "commensurate with the scientific understanding of natural laws" (Scott, 1998, p. 4), for instance, a comprehensive engineering of human settlement and production. Designing society top-down is schematic and ignores the essential realities of any truly existing social order: The constitutive uncertainties, fragility, and complexity of social, political, and economic events, the difficulty of anticipating the future present are treated as minor obstacles that can be encircled as soon as possible — of course by a top-down approach—by implementing policies that the faith in scientific knowledge prescribes. This undermines the dignities, pluralities, and conflicts that are immanent features of contemporary knowledge societies.

Finally, there is the remarkable resilience of advanced capitalist democracies confronted with major "shocks" from their beginnings in the early twentieth century through one of the most turbulent modern centuries. Democracy is a more effective adaptive organism than other forms of governance (Luce, 2017, p. 87) Although the past is not necessarily a solid foundation for anticipating the future state of affairs, there is "a near-zero probability of rich democracies reverting to authoritarianism" (Iversen \& Soskice, 2019; see also Przeworski \& Limongi, 1997). Obviously, exceptions exist. But one cannot yet know whether the exceptional circumstances of climate change in the future present will be of such magnitude that the past indeed can be no guide to the future health of democracies.

\section{What Is to Be Done? Enhancing Democracy?}

What is good governance under exceptional circumstances? Is democratic governance effective governance? And why should a more democratic as well as egalitarian society be beneficial as the socio-political foundation for coping with extreme circumstances?

In their disenchantment with democracy, the discourse of the impatient scientists privileges hegemonic players such as world powers, states, transnational organizations, and multinational corporations. Participatory strategies are only rarely in evidence. Likewise, global mitigation has precedence over local adaptation. "Global" knowledge triumphs over "local" knowledge. However, societal trends appear to operate into the opposite direction. The ability of large societal institutions to impose their will on citizens is declining (Stehr, 2001). As a result, people mobilize around local concerns and efforts, including those of the consequences of climate change- thereby enhancing the democratic in democratic governance.

The discussion of options for future climate policies supports the impression that the same failed climate policies must remain in place and are the only correct approach; it is simply that these policies have be become more effective and "rational." It follows that international negotiations must lead to an agreement for concrete, but much broader, emission reduction targets. Only a super-Kyoto can still help. But how the noble goals of a comprehensive emission reduction can be 
practically and politically enforced remains in the fog of general declarations of intent and only sharpens scientists' political skepticism.

The still dominant line of attack to climate policy shows little evidence of success, whether at the state level or on the global scale. On the contrary, everything that actors continues to set in motion worldwide is aimed at a persistent economic growth, which prevents emissions from declining. An alternative model is neededa model in which action under ambivalent, uncertain and unexpected circumstances can be compelled. A model whose utilizers recognize, moreover, that climate change is a wicked problem that can only be attacked indirectly and requires persistence over a longer period of time. That kind of model will only be found through revitalized rather than less democratic interaction.

Climate policy must be compatible with democracy, or the threat to civilization will be much more than just changes to the world's physical environment. Climate change demands complex solutions that require worldwide empowerment and knowledgeability of individuals, groups, and movements that labor on environmental issues. More democracy combined with political efforts to move toward a more equitable society could be the key toward sustainable climate policies. By definition, more democracy comes with greater political participation, especially among those now typically standing on the sidelines of political participation, such as the young and the economically disadvantaged strata. ${ }^{19}$

A more egalitarian society "would not necessarily maintain rational ecological policies, but it would be more likely to do so" (Best \& Connolly, 1975, p. 59). When life chances are more equally distributed, assuring that no one can escape the benefits and costs of a resolution of a serious public problem, ${ }^{20}$ one should expect that "the political system is very likely to generate collective responses to common dangers and burdens" (Best \& Connolly, 1975, p. 59). The English political scientist David Runciman (2013, p. 316) spells out two further distinct, practical advantages of democracies over authoritarian governments faced by extraordinary circumstances: „The first is their ability to pull together when the threat becomes too big to ignore ... The second is their ability to keep experimenting and adapting to the challenges they encounter.". 21

A war-like footing, in contrast, has exactly the opposite effect. A war-like approach reduces the complexity of social and political life in as much as war "nationalizes people's life. Private activities ... [are] largely shaped by collective constraints" (Rosanvallon, 2013, p. 183), as would be the case under authoritarian rule. Under modern conditions, the heightened cognitive and social abilities of ordinary citizens especially predicates successful policies and good governance on their political participation.

\footnotetext{
${ }^{19}$ Concrete advice on how to avoid oligarchic tendencies in organization may be found, for example, in Robert K. Merton's (1966) essay "Dilemmas of Democracies in the Voluntary Association." ${ }^{20}$ The systematic reduction of patterns of social inequality in modern societies enhances democratic governance and political participation (Soci, Maccagnan, \& Mantovani, 2014, p. 46).

${ }^{21}$ Hans Jonas (1984, p. 146) advances a similar observation about systematic inability of authoritarian governments to transcend policy mistakes.
} 
Moreover, a further denationalization of governance will assist in producing new, multiple forms of social solidarity and obligations, strengthen local/regional responses to climate change, and enhance the understanding of social interdependence. In addition, social institutions' self-sufficiency must be guaranteed and-if necessary-re-created in order to transcend boundaries, joining allegedly distinctive motives and practices of different social institutions, for example, joining economic and moral incentives and enhancing the complexity of needs.

The tendency to overestimate and overreach in assigning a crucial role to the singularity of knowledge (and information) in social conduct is evident as one considers how much knowledge is needed to carry a specific task, let alone how deeply and subtly one needs to know it. Curiosity about how much one needs to know also extends to the question of what one does not need to know. In the first instance, this happens to be an issue that is rarely systmatically examined. Second, the inclination is prevelant to assume that the resource of knowledge is somehow sufficient to carry a specific transaction. A more adequate conjecture would be to expect that actors carry out most decisions and actions with rather limited knowledge and information (cf. Akerlof, 1970; Smith, 2015) about future conditions of action and that they are cognizant of how little knowledge they are typically able to mobilize in many situations. The pressure to act that characterises everyday life ensures that, despite the limited knowledge and information of most actors, decisions are taken and action taken. The fact that actors are often forced to act with limited knowledge is not a constitutive deficiency of democracy. "Life cannot wait" (Durkheim, 1965, p. 479; see also Gehlen, 1988, pp. 296-297). In most social contexts, the need to act takes precedence over the need to know.

The erosion of democracy may seem "convenient" to some, such as populists, but surely is an unnecessary suppression of social complexity. Friedrich Hayek (1960, p. 25) pointed out a paradoxical development: As science advances, the observation that we should "aim at more deliberate and comprehensive control of all human activities" tends to strengthen. Hayek pessimistically adds: "It is for this reason that those intoxicated by the advance of knowledge so often become the enemies of freedom."

That democratic governance is slow compared, for example, to the speed at which with decisions are made in the modern economy (see Stehr \& Voss, 2019) cannot be denied. In the eyes of many citizens, naturally including climate scientists, the slowness and the deliberateness of decision making generates permanent discontent. Climate scientists, with their escalating warnings about imminent risks and dangers of climate change repercussions and their communication of politicians' failures to heed these forewarnings do nothing to stem such civil restlessness. Democratic actors therefore face the major challenge of speeding up political decision making as well as enhancing opportunities for participation in democratic decision making in places such as the workplace (cf. Herzog, 2019) and the local political community. 


\section{Conclusions}

Certain kind of states, driven by utopian plans and an authoritarian disregard for the values, desires and objections of their subjects, are indeed a mortal threat to human well-being. James Scott (1998, p. 7)

As an editor of Nature (December 4, 2014, p. 8) editorializes: "The magnitude of ... climate change is worryingly uncertain. Even more uncertain are the physical, social and economic side effects of global warming. There is every reason to believe that, by and large, they will be harmful." The central issue is no longer whether is climate change occurring. It is rather what should be done about it. Climate change is the biggest threat humanity has faced in historical times. Suspending democratic debate and decision making including extensive citizen participation in order to do what is necessary would either demand elevating experts to become decision makers or delegating power to policymakers (who happen to believe a certain group of experts). Neither the first, the technocratic or social engineering vision, nor the idea of a more authoritarian environmentalism has appeal.

I have collected and advanced arguments that speak to the need to enhance rather than abolish democracy as the best political foundation for policies suited to addressing climate change as a wicked problem. It is important to push back against simplified solutions to climate change. In debating, researching, and understanding climate and climate change, actors would do well to heed the complex interconnections of the climate system, but also the societal processes, practices, and tensions through which science, society, nature, and climate permeate, accompany, cover, and envelop each other (for such a theoretical perspective, see Stehr \& Machin, 2019).

\section{References}

Adolphe, J. (2018, November 11). Why are California wildfires so bad? The Guardian (London). Retrieved from https://www.theguardian.com/world/ng-interactive/2018/sep/20/ why-are-california-wildfires-so-bad-interactive

Aitken, M. (2012). Changing climate, changing democracy: A cautionary tale. Environmental Politics, 21, 211-229. https://doi.org/10.1080/09644016.2012.651899

Akerlof, G. A. (1970). The market for "lemons": Quality uncertainty and the market mechanism. The Quarterly Journal of Economics, 84, 488-500. https://doi.org/10.2307/1879431

Beeson, M. (2010). The coming of environmental authoritarianism. Environmental Politics, 19, 276-294. https://doi.org/10.1080/09644010903576918

Best, J. (2018). Technocratic exceptionalism: Monetary policy and the fear of democracy. International Political Sociology, 12, 328-345. https://doi.org/10.1093/ips/oly017

Best, M. H., \& Connolly, W. E. (1975). Market images and corporate power: Beyond the "economics of environmental management". In K. M. Dolbeare (Ed.), Public policy evaluation (pp. 41-74). Thousand Oaks: SAGE.

Bomberg, E. (2017). Environmental politics in the Trump era: An early assessment. Environmental Politics, 26, 956-963. https://doi.org/10.1080/09644016.2017.1332543

Churchman, C. W. (1967). Guest editorial: Wicked problems. Management Science, 14, B141-B142. 
Crouch, C. (2004). Post-democracy. Cambridge: Polity.

Dahl, R. A. (1977). On removing certain impediments to democracy in the United States. Political Science Quarterly, 92, 1-20. https://doi.org/10.2307/2148546

di Paola, M., \& Jamieson, D. (2018). Climate change and the challenges to democracy. University of Miami Law Review, 72, 369-424. Retrieved from https://repository.law.miami.edu/umlr/ vol72/iss $2 / 5$

Downs, A. (1972). Up and down with ecology: The "issue-attention cycle". The Public Interest, 28, 38-50.

Durkheim, E. (1965). The elementary forms of the religious life (J. W. Swain, Trans.). New York: Free. (Original work published 1912)

Elger, K., \& Schwägerl, C. (2011, March 21). Diktatur des Jetzt [Dictatorship of the now]. Der Spiegel. Retrieved from https://www.spiegel.de/spiegel/print/d-77531589.html

Elias, N. (1984). Knowledge and power: An interview by Peter Ludes. In N. Stehr \& V. Meja (Eds.), Society and knowledge: Contemporary perspectives on the sociology of knowledge (pp. 251-292). New Brunswick: Transaction.

Fischer, F. (2017). Climate crisis and the democratic prospect: Participatory governance in sustainable communities. Oxford, UK: Oxford University Press. https://doi.org/10.1093/ oso/9780199594917.001.0001

Foucault, M. (2005). Die Maschen der Macht [The meshes of power]. In M. Foucault (Ed.), Schriften in vier Bänden: Dits et Ecrits I-IV (Vol. 4, pp. 224-244). Frankfurt: Suhrkamp.

Fukuyama, F. (2018). Identity: Contemporary identity politics and the struggle for recognition. London: Profile.

Gauchat, G., \& Andrews, K. T. (2018). The cultural-cognitive mapping of scientific professions. American Sociological Review, 83, 567-595. https://doi.org/10.1177/0003122418773353

Gehlen, A. (1988). Man: His nature and place in the world. New York, NY: Columbia University Press. (Original work published 1904)

Giddens, A. (2009). The politics of climate change. Cambridge: Polity.

Gigerenzer, G., \& Garcia-Retamero, R. (2017). Cassandra's regret: The psychology of not wanting to know. Psychological Review, 124, 179-196. https://doi.org/10.1037/rev0000055

Gilley, B. (2012). Authoritarian environmentalism and China's response to climate change. Environmental Politics, 21, 287-307. https://doi.org/10.1080/09644016.2012.651904

Granovetter, M. (1985). Economic action and social structure: The problem of embeddedness. American Journal of Sociology, 91, 481-510. https://doi.org/10.1086/228311

Grundmann, R., \& Stehr, N. (2012). The power of scientific knowledge: From research to public policy. Cambridge, UK: Cambridge University Press. https://doi.org/10.1017/ CBO9781139137003

Haldane, A. (2013). Rethinking the financial network. In S. A. Jansen, E. Schröter, \& N. Stehr (Eds.), Fragile Stabilität-stabile Fragilität (pp. 243-278). Wiesbaden: Springer VS. https:// doi.org/10.1007/978-3-658-02248-8

Hayek, F. A. (1944). The road to serfdom. London: Routledge. https://doi.org/10.4324/9780203 991718

Hayek, F. A. (1960). The constitution of liberty. London: Routledge. https://doi.org/10.4324/978131 5832081

Herzog, L. (2019). Die Rettung der Arbeit [Saving the work]. Munich: Hanser Berlin.

Iversen, T., \& Soskice, D. (2019). Democracy and prosperity: Reinventing capitalism through a turbulent century. Princeton, NJ: Princeton University Press.

Jasanoff, S. (2012). Science and public reason. London: Routledge. https://doi. org/10.4324/9780203113820

Jamieson, D. (2014). Reason in a dark time: Why the struggle against climate change failed - and what it means for our future. New York, NY: Oxford University Press. https://doi.org/10.1093/ acprof:oso/9780199337668.001.0001

Jonas, H. (1984). The imperative of responsibility: In search of an ethics for the technological age. Human Studies, 11, 419-429. 
Keller, E. F. (2017). Climate science, truth and democracy. Studies in History and Philosophy of Biological and Biomedical Sciences, 64, 106-122. https://doi.org/10.1016/j.shpsc.2017.06.006

Kuklinski, J. H. (1990). Information and the study of politics. In J. A. Ferejohn \& J. H. Kuklinski (Eds.), Information and democratic processes (pp. 391-395). Urbana, IL: University of Illinois Press.

Kuttner, R. (2018). The crash that failed. The New York Review of Books, 65(18). Retrieved from https://www.nybooks.com/articles/2018/11/22/financial-crash-that-failed/?

Levitsky, S., \& Ziblatt, D. (2018). How democracies die: What history tells us about our future. New York: Crown.

Lipset, S. M. (1959). Some social requisites of democracy: Economic development and political legitimacy. American Political Science Review, 53, 69-105. Retrieved from http://www.jstor. org/stable/1951731

Lovelock, J. (2009). The vanishing face of Gaia: A final warning. New York: Basic.

Luce, E. (2017). The retreat of western liberalism. New York: Little, Brown and Company.

Luhmann, N. (1976). The future cannot begin: Temporal structure in modern society. Social Research, 43, 130-152. Retrieved from https://www.jstor.org/stable/40970217

Luhmann, N. (1998). Observations on modernity. Stanford, CA: Stanford University Press.

Luhmann, N. (2005). Risk: A sociological theory (with a new introduction by Nico Stehr and Gotthard Bechmann). London: Aldine Transaction.

Marquand, D. (2004). Decline of the public: The hollowing out of citizenship. Cambridge: Polity.

Marshall, G. (2014). Don't even think about it: Why our brains are wired to ignore climate change. New York: Bloomsbury.

Martin, S. L., Trow, M., \& Coleman, J. S. (1956/1962). Union democracy: The internal politics of the international typographical union. New York: Doubleday \& Company.

McDonald, S. (2009). Changing climate, changing minds: Applying the literature on media effects, public opinion, and the issue-attention cycle to increase public understanding of climate change. International Journal of Sustainable Communities, 4, 45-63.

McKibben, B. (2016, August 15). A world at war: We're under attack by a powerful enemy-and our only hope it to mobilize like we did in WWII. The New Republic (New York). Retrieved from https://newrepublic.com/article/135684/declare-war-climate-change-mobilize-wwii

McKibben, B. (2018, October 25). A very grim forecast. New York Review. Retrieved from https:// www.nybooks.com/articles/2018/11/22/global-warming-very-grim-forecast/

Merton, R. K. (1966). Dilemmas of democracy in the voluntary associations. The American Journal of Nursing, 66, 1055-1061. https://doi.org/10.1097/00000446-196605000-00039

Michels, R. (1915). Political parties: A sociological study of the oligarchical tendencies of modern democracy (E. Paul \& C. Paul, Trans.). New York: Hearst's International Library.

Mounk, Y. (2018). The people vs. democracy: Why our freedom is in danger \& how to save it. Cambridge, MA: Harvard University Press.

Nordhaus, W. (2013). The climate casino: Risk, uncertainty, and economics for a warming world. New Haven, CT: Yale University Press.

Petersen, M. B., \& Aarøe, L. (2013). Politics in the mind's eye: Imagination as a link between social and political cognition. American Political Science Review, 107, 275-293. https://doi. org/10.1017/S0003055413000026

Pielke, R. (2010). The climate fix: What scientists and politicians won't tell you about global warming. New York: Basic.

Prewitt, K. (2010). Introduction: Limits to knowledge? No easy answer. Social Research, 77, 901-904. Retrieved from https://www.jstor.org/stable/40972298

Prins, G., Galiana, I., Green, C., Grundmann, R., Hulme, M., Korhola, A., Laird, F., Nordhaus, T., Pielke, R., Rayner, S., Sarewitz, D., Shellenberger, M., Stehr, N., \& Tezuka, H. (2010). The Hartwell paper: A new direction for climate policy after the crash of 2009. London, UK: London School of Economics and Political Science.

Przeworski, A., \& Limongi, F. (1997). Modernization: Theories and facts. World Politics, 49, 155-183. https://doi.org/10.1353/wp.1997.0004 
Revkin, A. C. (2014, April 16). A risk analyst explains why climate change risk misperception doesn't necessarily matter. The New York Times. Retrieved from https://dotearth.blogs.nytimes. com/2014/04/16/a-risk-analyst-explains-why-climate-change-risk-misperception-doesnt-necessarily-matter/?_php=true\&_type=

Rittel, H. W. J., \& Webber, M. M. (1973). Dilemmas in a general theory of planning. Policy Sciences, 4, 155-169. https://doi.org/10.1007/BF01405730

Rosanvallon, P. (2006). Democracy: Past and future. New York, NY: Columbia University Press.

Rosanvallon, P. (2013). The society of equals. Cambridge, MA: Harvard University Press.

Rorty, R. (2004). Post-democracy: Richard Rorty on anti-terrorism and the national security state. London Review of Books, 26(7), 10-11. Retrieved from https://www.lrb.co.uk/the-paper/v26/ n07/richard-rorty/post-democracy

Runciman, D. (2013). The confidence trap: A history of democracy in crisis from World War I to the present. Princeton, NJ: Princeton University Press.

Runciman, D. (2018). How democracy ends. London: Profile.

Sarewitz, D. (2010). Normal science and the limits on knowledge: What we seek to know, what we choose not to know, what we don't bother knowing. Social Research, 77, 997-1010. Retrieved from https://www.jstor.org/stable/40972304

Schön, D. A. (1963). Invention and the evolution of ideas. London: Tavistock.

Schumpeter, J. A. (1942). Capitalism, socialism and democracy. New York: Harper \& Brothers.

Scott, J. C. (1998). Seeing like a state: How certain schemes to improve the human condition have failed. New Haven, CT: Yale University Press.

Seefried, E. (2015). Zukünfte: Aufstieg und Krise der Zukunftsforschung 1945-1980 [Futures: The Rise and Crisis of Futurology 1945-1980]. Berlin: De Gruyter Oldenbourg.

Shearman, D., \& Wayne, J. (2007). The climate challenge and the failure of democracy. Westport: Praeger.

Simmel, G. (1890). Über sociale Differenzierung: Sociologische und psychologische Untersuchungen [On social differentiation: Sociological and psychological studies]. Leipzig: Duncker \& Humblot.

Skidelsky, R. J. A., \& Skidelsky, E. (2012). How much is enough? Money and the good life. New York: Other.

Soci, A., Maccagnan, A., \& Mantovani, D. (2014). Does inequality harm democracy? An empirical investigation on the UK. Paper presented at the Sixth International Scientific Conference on Economic and Social Development and Third Eastern European ESD Conference: Business Continuity, Vienna. Paper retrieved from https://bib.irb.hr/datoteka/759841.Book_of_ Proceedings_esd_Vienna_2014.pdf\#page $=54$

Smith, C. W. (2015). What the market teaches us: Limitations of knowing and tactics for doing. Oxford, UK: Oxford University Press. https://doi.org/10.1093/acprof: oso/9780198745112.001.0001

Stehr, N. (1991). The power of scientific knowledge — and its limits. Canadian Review of Sociology and Anthropology, 28, 460-482. https://doi.org/10.1111/j.1755-618X.1991.tb00165.x

Stehr, N. (1994). Knowledge societies. London: SAGE.

Stehr, N. (1997). Trust and climate. Climate Research, 8, 163-169. https://doi.org/10.3354/ cr008163

Stehr, N. (2001). The fragility of modern societies: Knowledge \& risk in the information age. London: SAGE.

Stehr, N. (2015). Climate policy: Democracy is not an inconvenience. Nature, 525, 449-450. https://doi.org/10.1038/525449a

Stehr, N. (2016a). Information, power, and democracy: Liberty is a daughter of knowledge. Cambridge, UK: Cambridge University Press. https://doi.org/10.1017/CBO9781316343159

Stehr, N. (2016b). Exceptional circumstances: Does climate change trump democracy? Issues in Science and Technology, 32, 37-44. 
Stehr, N., \& Adolf, M. (2018). Ist Wissen Macht? Wissen als gesellschaftliche Tatsache [Is knowledge power? Knowledge as social fact]. Weilerswist-Metternich: Velbrück Wissenschaft. https://doi.org/10.5771/9783845298948

Stehr, N., \& Machin, A. (2016a). Inequality in modern societies: Causes, consequences and challenges. In N. Stehr \& A. Machin (Eds.), Understanding inequality: Social costs and benefits (pp. 3-36). Wiesbaden: Springer VS. https://doi.org/10.1007/978-3-658-11663-7

Stehr, N., \& Machin, A. (2016b). Trusting the climate: Catastrophe vs. stability. Society, 53, 573-580. https://doi.org/10.1007/s12115-016-0069-6

Stehr, N., \& Machin, A. (2019). Society and climate: Transformations and challenges. Singapore: World Scientific.

Stehr, N., \& Voss, D. (2019). Money: A theory of modern society. New York: Routledge. https:// doi.org/10.4324/9780429331565

Swyngedouw, E. (2010). Apocalypse forever? Post-political populism and the spectre of climate change. Theory, Culture and Society, 27, 213-232. https://doi.org/10.1177/0263276409358728

Swyngedouw, E. (2011). Interrogating post-democratization: Reclaiming egalitarian political spaces. Political Geography, 30, 370-380. https://doi.org/10.1016/j.polgeo.2011.08.001

Tenbruck, F. H. (1977). Grenzen der staatlichen Planung [Limits of national planning]. In W. Hennis, P. G. Kielmansegg, \& U. Matz (Eds.), Regierbarkeit: Studien zu ihrer Problematisierung (Vol. 1, pp. 134-149). Stuttgart: Klett-Cotta.

van Dijk, T. A. (2014). Discourse and knowledge: A sociocognitive approach. Cambridge, UK: Cambridge University Press. https://doi.org/10.1017/CBO9781107775404

Williamson, O. E. (1975). Markets and hierarchies: Analysis and antitrust implications. New York: Free.

Williamson, O. E. (1985). The economic institutions of capitalism: Firms, markets, relational contracting. New York: Free.

Williamson, O. E. (1994). Transaction cost economics and organization theory. In N. J. Smelser \& R. Swedberg (Eds.), The handbook of economic sociology (pp. 77-107). Princeton, NJ: Princeton University Press.

WBGU. (2012). Welt im Wandel-Gesellschaftsvertrag für eine Große Transformation [World in transition-Society contract for a Great Transformation]. Retrieved from https://www.wbgu.de/de/publikationen/publikation/ welt-im-wandel-gesellschaftsvertrag-fuer-eine-grosse-transformation

Zakaria, F. (2003). The future of freedom: Illiberal democracy at home and abroad. New York: Norton.

Open Access This chapter is licensed under the terms of the Creative Commons Attribution 4.0 International License (http://creativecommons.org/licenses/by/4.0/), which permits use, sharing, adaptation, distribution and reproduction in any medium or format, as long as you give appropriate credit to the original author(s) and the source, provide a link to the Creative Commons license and indicate if changes were made.

The images or other third party material in this chapter are included in the chapter's Creative Commons license, unless indicated otherwise in a credit line to the material. If material is not included in the chapter's Creative Commons license and your intended use is not permitted by statutory regulation or exceeds the permitted use, you will need to obtain permission directly from the copyright holder.

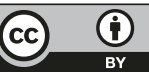

